\title{
Proximate Analysis and Microbial Quality of Ready-To-Eat (RTE) Fried Chicken Parts
}

\author{
Osakue OP' ${ }^{1}$ Igene $\mathrm{JO}^{1}$, Ebabhamiegbebho $\mathrm{PA}^{1}$ and Evivie $\mathrm{SE}^{2^{*}}$ \\ ${ }^{1}$ Food Science and Nutrition Unit, Department of Animal Science, Faculty of Agriculture,University of Benin, PMB 1154, Benin City, Nigeria \\ ${ }^{2}$ Key Laboratory of Dairy Science-Ministry of Education (KLDS-MOE), College of Food Sciences, Northeast Agricultural University, Harbin, 150030, PR China
}

\begin{abstract}
Fried chicken samples were sourced from two vending sites (from street vendors and fast food centers) in Ikpoba Okha, Oredo and Egor LG as in Benin City. Bacteria growth was observed using Nutrient Agar, the presence of E.coli was detected using Eosine Methylene Blue and Fungi growth was observed by using Potato Dextrose Agar. Proximate composition for the fried chicken samples indicated that the mean value for Moisture content ranged from $55.67-59.15 \%$, Crude protein $26.62-30.52 \%$, Crude fat $7.87-8.72 \%$, Ash $3.06-3.88 \%$ and Nitrogen free extract $0.10-2.50 \%$. The results obtained indicated that the mean values of bacteria count ranged from $4.67 \times 10^{6}$ to $1.2 \times 10^{7} \mathrm{cfu} / \mathrm{g}$. The sample from the eatery in Oredo had the highest bacterial count of $1.2 \times 10^{7} \mathrm{cfu} / \mathrm{g}$. Thirteen genera of bacteria and seven genera of fungi were isolated. Total fungal counts ranged from 4.70 $\times 10^{5}$ to $2.615 \times 10^{6} \mathrm{cfu} / \mathrm{g}$. The fried chicken from the street in Ikpoba Okha recorded the highest count with2.615× $10^{6} \mathrm{cfu} / \mathrm{g}$. The fried chicken samples from the eateries had no E.coli and other serious food-borne pathogens; such as Klebsiella sp, Enterobacter $s p$. The aerobic colony counts of bacteria and fungi were higher thanInternational Food Standards $\left(<10^{5} \mathrm{cfu} / \mathrm{g}\right)$, notwithstand the absence of food-borne microbial pathogens such as E.coli and other serious food-borne pathogens from the eateries and therefore, the products as observed would appear unsafe for human consumption. The isolation and enumeration of bacteria and fungi isolates were also observed. The significance of isolated bacteria and fungi in the fried chicken samples, possible sources of contamination and some recommendations to improve the quality of fried chicken sold in these vending sites were discussed.
\end{abstract}

Keywords: Chicken parts; Microbial quality; Public health; Readyto-Eat (RTE) food

\section{Introduction}

Ready-to-Eat (RTE) food is a term given to food that can be consumed by consumers directly at the point of sale without further treatment $[1,2]$. These foods is consumed in the same state and do not require heating, peeling and washing unlike fruits and vegetables which have nuts and shells. Examples of ready-to-eat foods include fried chicken, sausages, meat pies and other take away foods. Processing of these value-added products require strict hygiene applications throughout the processing chain. This is because chicken meat / chicken based products are susceptible to microbial spoilage and could harbor pathogens even under the best management conditions and practices $[3,4]$. However, due to the busy schedule of individuals as a result of modern life style, industrialization and lack of time to prepare proper meals, large populations of individuals depend on ready-to-eat food which has resulted in less family or home centered activities [5]. The number of restaurants and sales outlets of ready-to-eat food in the country have greatly increased as institutions which offer degree programs in catering, home management and other related courses have paved way for qualified individuals to be employed thus reducing the rate of unemployment [6].

The sale of fried chicken parts is a common site at strategic busy areas in Benin City. Fried chicken parts are usually sold in the open markets along major streets in Benin City and in some fast food centres. Such areas include Ring road (Oredo), UseluLagosroad (Egor) and Cara market (Ikpoba Okha). The ways they are displayed for sale to the general public coupled with the handling practices call to question the hygiene status of the products. The products are displayed on open trays which are easily contaminated by dust, exhaust smoke, sand, insects, hands of intending buyers etc. According to Yah et al. [6], food-borne diseases are diseases resulting from the ingestion of bacteria, toxins and cells produced by microorganisms present in food. Organisms that cause food-borne diseases include E.coli, Bacillus species, Clostridium botulinum, molds, fungi and yeast. The health implications in consuming fried chicken sold along the streets and in some fast foods stores have been of great concern for a long time [7]. Food-borne illnesses of microbial origin are a major health problem associated with fried chicken parts sold in public places. The most commonly reported practice that contributed to food-borne disease was bare-handed contact by handler/worker/preparer [8]. Most consumers who depend on such food are more interested in its convenience and usually pay little attention to its safety, quality and hygiene $[9,10]$. Under these circumstances, microbiological evaluation can often be very helpful to ascertain the safety and avoid public health hazards among consumers of fried chicken parts.

Determine the proximate chemical analysis of the eateries and street vended fried chicken. The major concern with street foods is their microbiological safety, mainly because vending is done in places that may have poor sanitation. In general the numbers and types of microorganism present in a finished food products are influenced by the general environment from which the food was originally obtained, the bacteriological.

*Corresonding author: Evivie SE, Key Laboratory of Dairy Science-Ministry of Education (KLDS-MOE), College of Food Sciences, Northeast Agricultural University, Harbin, 150030, PR China, Tel:+86 4518639 0111;E-mail: besta_intercom@yahoo.com

Received Octomber 06, 2015; Accepted March 18, 2016; Published March 21 2016

Citation: Osakue OP, Igene JO, Ebabhamiegbebho PA, Evivie SE (2016) Proximate Analysis and Microbial Quality of Ready-To-Eat (RTE) Fried Chicken Parts. J Food Ind Microbiol 2: 107. doi:10.4172/2572-4134.1000107

Copyright: (c) 2016 Osakue OP, et al. This is an open-access article distributed under the terms of the Creative Commons Attribution License, which permits unrestricted use, distribution, and reproduction in any medium, provided the original author and source are credited. 
Quality of the food in its raw or unprocessed state, the sanitary conditions under which the product is handled and processed and the adequacy of subsequent packaging, handling, storage conditions of the products [11]. The broad objective of this work are to Isolate, estimate, identify and characterize microorganisms (bacteria, fungi) from readyto-eat fried chicken, obtained from different fast food centers and street vended spots in Benin City, Nigeria. It also compares the microbial load of ready-to-eat fried chicken collected from these fast food centers and street vended spots.

\section{Materials and Methods}

\section{Study area}

The study areas are the eateries and vendors at the roadside using three different locations (Local Government Areas) in Benin City, Edo State. They are: Uselu Lagos road (Egor LGA), Lagos street (Oredo LGA) and Cara market (Ikpoba Okha LGA). These areas were selected because fried chicken parts are mainly sold there and there is high patronage of street vended foods.

\section{Sample collection}

A fried chicken part (Drumstick) was bought from each vending site, making a total of two replicate samples collected from each Local Government Areas at two weeks interval. From each of the sites, ready-to-eat fried chicken samples were purchased from an eatery and a vendor at the road side and transported to the laboratory as being sold andwrapped with transparent nylon by the handlers and kept in a deep cold storage at $4^{\circ} \mathrm{C}$ and analyzed within 12 hours of collection. The complete process of microbiological analysiswas performed under a sterile condition to avoid contamination from environment. The samples were subjected to microbiological analysis according to standard procedures.

\section{Control sample (Laboratory prepared)}

Chicken was purchased from the farm house of the University of Benin. Utensil used for killing and dressing the chicken were properly washed. The chicken was killed, properly scalded, cut into desirable sizes and properly seasoned, boiled in $500 \mathrm{ml}$ of water and afterwards deep fried in hot vegetable oil. After frying, fried parts were kept in the refrigerator properly packaged. The drumstick of the chicken was used as the control.

\section{Sterilization of media}

The experiment was conducted at the main laboratory of the Faculty of Agriculture,University of Benin. The glassware's such as test tubes, glass rod, pipette, measuringcylinder, beakers and conical flasks required for this research work were soaked and washed with detergent and rinsed with distilled water. They were wrapped with aluminumfoil paper and dried in the oven in inverted position at $80^{\circ} \mathrm{C}$ for $45-60$ mins. The working area was swabbed with ethanol. Contamination by microorganisms from the external environment was reduced by closing windows and putting off fans in the laboratory.

\section{Microbiological analysis}

The samples studied were analyzed using standard microbiological methods according to Buchanan et al. [12] for the bacteria samples; while the identification and characterization of the fungi was done according to Barnett and Hunter [13].

\section{Preparation of culture media}

Nutrient agar (NA) for bacterial evaluation: $28 \mathrm{~g}$ of Nutrient Agar was weighed with a top loading balance and dissolved in 1 liter of distilled water in a conical flask covered with cotton wool and aluminum foil paper.

It was mixed thoroughly and sterilized using a pressure cooker at a temperature of $121^{\circ} \mathrm{C}$ for 15 mins. The medium was cooled to $45-59^{\circ} \mathrm{C}$ and then dispensed aseptically into sterile petridishes. The petridishes were covered and allowed to solidify.

Potato dextrose agar (PDA) for fungi evaluation: $39 \mathrm{~g}$ of Potato Dextrose Agar was weighed with a top loading balance and dissolved in 1liter of distilled water in a conical flask covered with cotton wool and aluminum foil paper. It was mixed thoroughly and sterilized using a pressure cooker at a temperature of $121^{\circ} \mathrm{C}$ for $15 \mathrm{~min}$. The medium was cooled to $45-59^{\circ} \mathrm{C}$ and then dispensed aseptically into sterile petridishes. The petridishes were covered and allowed to solidify.

Culturing and isolation of fried chicken samples: $1 \mathrm{~g}$ of each fried chicken sample was homogenized in $10 \mathrm{ml}$ of sterile distilled water.

$1 \mathrm{ml}$ was pipetted from it and added to next blank distilled water, making a dilution of $10^{-2}$. Dilutions were made by mixing $1.0 \mathrm{ml}$ of the homogenate in $9.0 \mathrm{ml}$ of sterile distilled waterto obtain $10^{-3}$ dilution. The dilution was then made to $10^{-4}, 10^{-5}$ and $10^{-6}$. Total viable counts of bacteria were determined by enumerating the colony forming units (cfu/g) bypour plating $1.0 \mathrm{ml}$ of $10^{-5}$ diluents on nutrient agar plates supplemented with anti-fungimixture to inhibit fungi growth and incubated at $37^{\circ} \mathrm{C}$ for $48 \mathrm{hrs}$.

Total fungal counts weredetermined by pour plating on Potato Dextrose Agar plates supplemented with antibioticmixture to inhibit bacterial growth, and incubated at room temperature $\left(26 \pm 2^{\circ} \mathrm{C}\right)$ for 72 hrs and the presence of Escherichia coli was detected by pour plating on Eosine Methylene Blue (EMB) agar plates and incubated at $37^{\circ} \mathrm{C}$ for $48 \mathrm{hrs}$. Samples that were positive showed a greenish metallic sheen which is the appearance of Escherichia coli. The experiments were carried out in triplicates. Pure cultures of bacterial and fungal isolates were obtained on the Nutrient Agar and Potato Dextrose Agar plates respectively.

\section{Enumeration of bacterial isolates}

At the end of the incubation period, the plates were read and observed for growth. The population of the bacterial isolates was estimated by counting the number of discrete colonies in the plate. Morphological and cultural characteristics were observed. Discrete colonies were sub cultured by streak plate method in order to obtain pure culture. Stock cultures of each colony were prepared in the agar slants which were incubated for $24 \mathrm{hrs}$ toallow for growth after which they were stored at $4^{\circ} \mathrm{C}$ in the refrigerator for further experimentation.

\section{Gram staining}

Gram staining was carried out as described by AOAC [14]. A drop of sterile distilled water was placed on a clean grease free slide. The inoculating wire loop was flamed until red hot. The loop was allowed to cool and a small portion of the organism to be gram stained was picked and smeared in the drop of water on the slide. The slide was then air dried. It was heat fixed by passing it gently over flame. The smear was stained with $1 \%$ crystal violet for 1 minute and washed with distilled water. Gram iodine was added as a mordant for $1 \mathrm{~min}$. this was drained off and $70 \%$ alcohol was added for 30 seconds. This acted as a 
decolorizer. The above is termed primary staining. The slide was then rinsed with distilled water. The slide was finally flooded with counter stain, safranin for $1 \mathrm{~min}$ and washed off with distilled water and air dried. The slide was observed under the microscope oil immersion $\times$ 100 objective lens. The Gram positive organisms appeared purple while the Gram negative organisms appeared red.

\section{Biochemical test}

Coagulase test: This test is used to determine the enzyme coagulase that differentiates between pathogenic strains of staphylococcus. A colony of the test organisms was emulsified with sterile normal saline solution on a clean slide using a sterile wire loop. A drop of rabbit plasma was added and mixed with emulsion. The positive coagulase organisms showed clumping while negative coagulase organisms showed no clumping.

Catalase test: This test is used to demonstrate the presence of enzyme catalase, which catalyzes the release of oxygen from hydrogen peroxide. The pure culture of the test organism was placed and added to a drop of $3 \%$ hydrogen peroxide solution on a clean slide. The production of gas bubble from the surface indicates positive result.

Oxidase test: This test was carried out to detect the production of the enzyme oxidase by the bacteria isolates. A piece of filter paper was soaked in a few drop of oxidase reagent (tetramethyl-p-phenyldiamine-dihydrochloride). A colony of the test organism was then smeared on the soaked filter paper. An oxidase producing organisms on the filter paper oxidized the phenyl-diamine in the reagent to deep purple colour. This change in colour to deep purple within 10seconds indicates positive result.

Citrate test: This test detects the ability of an organism to use citrate as the sole source of carbon and energy and ammonium salt as the sole source of nitrogen. Simmon citrate agar is used for the preparation of the media. The test is usually used as an aid in the differentiation of organisms in the Enterobacteriaceae and most other genera. The medium used for this testwas the Simon's citrate agar was inoculated within $24 \mathrm{hrs}$ culture of the isolates. The inoculation was done by stabbing the medium using sterile straight inoculating wire. Theinoculated medium was then incubated at $3^{\circ} \mathrm{C}$ for about 24 hours. Change in colour from green to blue after about 24 hours of incubation indicated positive result.

\section{Identification of fungal isolates}

Smears of the pure culture of the fungal isolates were made on clean slide and Lactophenol cotton blue reagent was added for 1minute and after which it was rinsed with distilled water. Then 95\% ethanol was added for $30 \mathrm{~s}$ and rinsed again and viewed under the microscope.

\section{Proximate composition}

The Proximate composition for moisture, protein, fat and ash was determined according to AOAC [14]. The crude protein content was determined by the Kjedahl method and the crude fat content was determined by solvent extraction using the Soxhlet technique. The fried chicken sample was first hydrolyzed with boiling $\mathrm{HCl}$ before extraction with petroleum ether. Each extracted group was then dried in a forced air oven at $105^{\circ} \mathrm{C}$ for $3 \mathrm{hrs}$ (to constant mass), cooled in desiccator and then weighted to obtain the dry solids content. To determine ash content, fried chicken sample $(1 \mathrm{~g})$ were minced, weighed and ignited in the crucible. Then it was transferred in the muffle furnace held at dark red ata rate of $550^{\circ} \mathrm{C}$ for $6-8 \mathrm{hrs}$ until the residue was white.
Moisture content was determined bydrying the samples overnight at $105^{\circ} \mathrm{C}$.

Calculation of moisture:

Moisture $(\%)=\frac{\text { Weight loss } \times 100}{\text { Original weight of the sample } 1}$

Calculation of crude protein:

$N_{2}(\%)=\frac{0.00014 \times \text { Vol of acid } \times \text { Filteration flask for preparation of digest } \times 100}{\text { Weight of sample } \times \text { Amount of digest introduced into the flask }}$

Protein $(\%)=\%$ of total $\mathrm{N}_{2} \times 6.25$

Calculation of crude fat:

Fat $(\%)=\frac{\text { Weight of the oil } \times 100}{\text { Weight of the samples taken } 1}$

Calculation of ash:

$$
\text { Ash }(\%)=\frac{\text { Weight of ash } \times 100}{\text { Original weight of the sample taken } 1}
$$

Statistical Analysis

All data collected from the experiment were subjected to the Analysis of Variance (ANOVA) using GenStat package (12.1 versions). The separation of means was carried out using Duncan's Multiple Range test at $5 \%$ level of probability $(\mathrm{P}<0.05)$.

\section{Results and Discussion}

\section{Proximate analysis}

The proximate composition of fried chicken samples prepared in the laboratory (Control) and Fried chicken bought in different locations in Benin Metropolis are shown in Figure 1. For the moisture content of fried chicken there was no significant difference $(\mathrm{P}>0.05)$ in the eateries and street vended chicken of Oredo and Egor LGAs. However there was significant difference $(\mathrm{P}<0.05)$ in the street vended chicken and eatery of Ikpoba Okha. The control differed significantly $(\mathrm{P}<0.05)$ from the three Local Government Areas; with moisture content value of $55.67 \%$ which means that the control which is the laboratory prepared had the least moisture content. Frying reduces the moisture in food. As reported by Varela et al. [15], when frying food, the hot frying fat that has penetrated into it, replaces part of the water it contains, making the food considerably more palatable. The reason why it appears that the eateries and the street vended meat had high moisturecontent as compared to the laboratory prepared is obvious, the commercial one would not like to fry their meat to that point where it reduces yield and dry; but would rather want more moisture in the meat in order to increase yield (more weight). The high moisture content of fried chicken sold in the eateries was also probably due to the use of microwave to warm the meat before serving.

There was significantdifferences $(\mathrm{P}<0.05)$ in the Crude protein of street vended chicken and eateries of Ikpobaokha and Oredo LGAs, except in Egor LGA where the street vended chicken and eatery were not significantly different $(\mathrm{P}>0.05)$. The control differed significantly $(\mathrm{P}<0.05)$ from the eateries and street vended meat of the three Local Government Areas. It had the highest crude protein value of $30.52 \%$. Crude protein content is a factor of the diet of the chicken and these chickens are sought from different locations. The variation in crude protein may be as a result of differences in species, production, sex and age of the animal etc. The crude fat content of street vended chicken and eatery of Ikpobaokha did not differ significantly $(\mathrm{P}>0.05)$ from the street vended meat of Oredo. It was however, different from the chicken sold in the eatery of Oredo. There was no significant difference 


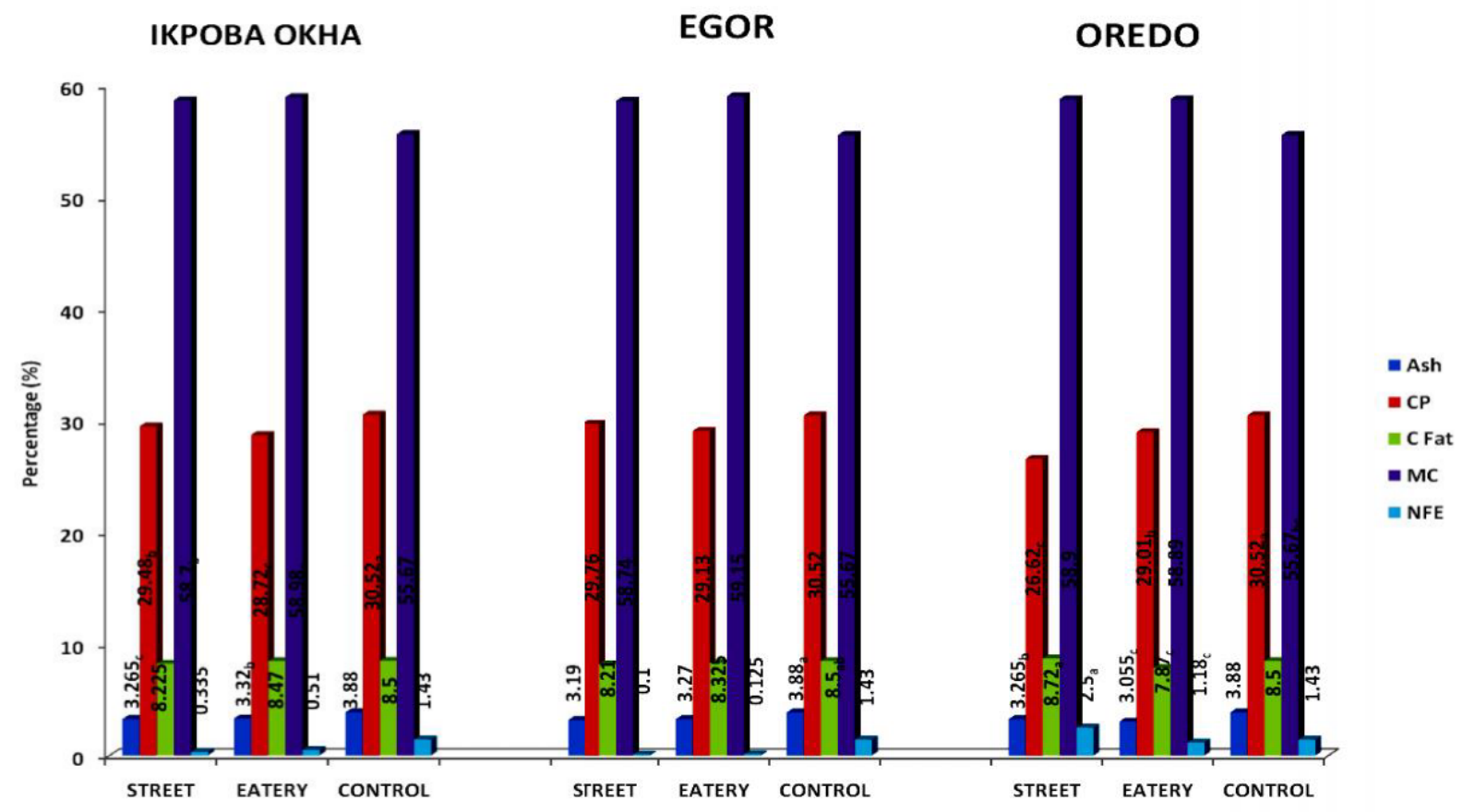

Figure 1: Proximate composition of fried chicken tissues sold ineatery and street with the control in Benin Metropolis. Meanvalue with subscript shows significant difference $(P<0.05)$ within the local government area.

$(\mathrm{P}>0.05)$ in the street vended chicken of Egor and the laboratory prepared. The composition of chicken meat as edible raw carcass meat has a crude fat content of $6.10 \%$ as documented by Olomu [16].

The average high fat content (value) of fried chicken might have been as a result of the absorption of fat during frying in oil [17] or what is usually practiced by most commercial vendors, refrying of leftover meat for subsequent day sales, which is in agreement with the findings of Pinthuset al. [18] who stated that during repeated frying, the polarity of oil increases and theinterfacial tension decreases.

Ash content was highest in the control (3.88\%), it differed significantly $(\mathrm{P}<0.05)$ from the meat sold in Ikpoba Okha, Oredo and Egor. The ash content of Street vended meat in Ikpoba Okha differed significantly $(\mathrm{P}<0.05)$ from the street vended meat in Oredo and Egor LG As the eatery in Ikpoba Okha did not differ significantly $(\mathrm{P}>0.05)$ from the eatery in Egor; but differed significantly $(\mathrm{P}<0.05)$ from the eatery in Oredo. The mineralcontent of meat (shown as 'ash' in Figure 1) include calcium, phosphorus, sodium, potassium and some trace elements like zinc, iron etc. The high values of the ash content correspond to the findings of Saguy and Dana [19]. They stated that during deep frying, the time required is generally short and the temperature inside the product remains below $100^{\circ} \mathrm{C}$, but there is less loss of water soluble vitamin. However, nutrients such as minerals, carbohydrate and proteins are retained. The variable results of these parameters are in line with the findings of Huss [20]; who observed that the chemical composition of animal tissue varies from species to species as well as from individual animals depending on age, sex, environment and season. Figure 2, shows the graphical representation of the statistical analysis of the proximate composition of fried chicken samples. The subscript shows the significant difference $(\mathrm{P}<0.05)$ within each Local Government Area.
Mean value with subscript shows significant difference $(\mathrm{P}<0.05)$ within the Local Government Area.

\section{Microbial analysis}

Thirteen genera of bacteria and seven genera of fungi were isolated from fried chicken (Table 1). Microbiological quality of fried chicken samples on the bases of the mean colony forming unit of the total bacteria and fungi per gram of fried chicken sample from both the street vendor and the standard eatery is shown in Table 2. The frequency of occurrence (\%) of each microbial isolate was also determined (Tables 2 and 3). The highest number of isolates was obtained from fried chicken sold in the eatery in Oredo with a percentage diversity of $21.1 \%$ (Table 4). Aspergillus niger had a frequency of (9.9\%). It was the only fungi isolated from all the fried chicken samples. Figure 2 is a graphical representation of the statistical analysis of the mean bacterial and fungi colonies per plate in the two vending sites in the different locations in Benin Metropolis. The superscripts show significant difference across the Local Government Areas; while the subscript shows significant difference within the LGAs.

The microbiological analysis of fried chicken samples obtained from the different vending sites in IkpobaOkha, Oredo and Egor LGAs in Benin City, Edo State is shown in Table 1. Laboratory prepared fried chicken served as control, had mean bacteria count of $4.670 \times$ $10^{6} \mathrm{cfu} / \mathrm{g}$; the street vended chicken range from $5.8 \times 10^{6} \mathrm{cfu} / \mathrm{g}$ to 1.12 $\times 10^{7} \mathrm{cfu} / \mathrm{g}$ and thechicken from the eatery ranged between 6.985 a $10^{6}$ to $1.20 \times 10^{7} \mathrm{cfu} / \mathrm{g}$. Statistical analysis of the mean bacteria load showed no significant difference $(\mathrm{P}>0.05)$ between the eatery and street fried chicken of IkpobaOkha, Oredo and Egor. However, the street vended fried chicken in the threeLGas differ significantly $(\mathrm{P}<0.05)$ from the control. It was only the eatery from Oredo that differed significantly $(\mathrm{P}<0.05)$ from the control sample. The results obtained were nearly 
Citation: Osakue OP, Igene JO, Ebabhamiegbebho PA, Evivie SE (2016) Proximate Analysis and Microbial Quality of Ready-To-Eat (RTE) Fried Chicken Parts. J Food Ind Microbiol 2: 107. doi:10.4172/2572-4134.1000107

Page 5 of 8

\begin{tabular}{|c|c|c|c|}
\hline Sampling point & Vending site & Mean number of Bacterial colonies per plate. (Cfu/g \pm SEM) & $\begin{array}{l}\text { Average number of Fungi colonies per plate. (Cfu/g } \\
\qquad \pm \text { SEM) }\end{array}$ \\
\hline \multirow[t]{2}{*}{ IkpobaOkha } & Street & $9.730 \times 10^{6}{ }_{a} \pm 3.76$ & $2.615 \times 10^{6} \pm 2.31$ \\
\hline & Eatery & $6.985 \times 10^{6}{ }_{\mathrm{ab}} \pm 1.47$ & $1.7 \times 10^{6}{ }_{a} \pm 1.08$ \\
\hline \multirow[t]{2}{*}{ Oredo } & Street & $5.8 \times 10_{\mathrm{a}}^{6} \pm 1.88$ & $1.385 \times 10^{6}{ }_{a} \pm 1.44$ \\
\hline & Eatery & $1.2 \times 10^{7} \pm 3.15$ & $1.9 \times 10^{6} \pm 2.50$ \\
\hline \multirow[t]{2}{*}{ Egor } & Street & $1.12 \times 10^{7} \pm 1.19$ & $1.75 \times 10^{6} \pm 2.39$ \\
\hline & Eatery & $1.00 \times 10^{7}{ }_{a b} \pm 1.19$ & $7.85 \times 10^{5} \pm 0.23$ \\
\hline Control & & $4.67 \times 10^{6}{ }_{b} \pm 1.40$ & $4.70 \times 10_{b}^{5} \pm 0.19$ \\
\hline
\end{tabular}

Values with different subscripts differ significantly

Table 1: Fungi and bacteria counts, in colony forming units per gram (cfu/g) of fried chicken sample.

\begin{tabular}{|c|c|c|c|c|c|c|c|c|c|}
\hline \multirow{2}{*}{ Isolates } & \multirow{2}{*}{ No } & \multirow{2}{*}{$\%$} & \multicolumn{2}{|c|}{ IkpobaOkha } & \multicolumn{2}{|l|}{ Oredo } & \multicolumn{2}{|l|}{ Egor } & \multirow{2}{*}{ Control } \\
\hline & & & Street & Eatery & Street & Eatery & Street & Eatery & \\
\hline Proteussp. & 7 & 9.9 & $\checkmark$ & & $\checkmark$ & $\checkmark$ & $\checkmark$ & $\checkmark$ & $\checkmark$ \\
\hline Micrococcussp. & 6 & 8.5 & $\checkmark$ & $\times$ & $\checkmark$ & $\checkmark$ & $\checkmark$ & $\checkmark$ & $\checkmark$ \\
\hline Staphylococcusaureus & 7 & 9.9 & $\checkmark$ & $\checkmark$ & $\checkmark$ & $\checkmark$ & $\checkmark$ & $\checkmark$ & $\checkmark$ \\
\hline Streptococcussp. & 3 & 4.2 & $\checkmark$ & $\checkmark$ & $\checkmark$ & $x$ & $x$ & $\times$ & $x$ \\
\hline Escherichiacoli & 3 & 4.2 & $\checkmark$ & $\checkmark$ & $\checkmark$ & $x$ & $\checkmark$ & $\times$ & $\times$ \\
\hline Klebsiellasp. & 3 & 4.2 & $\checkmark$ & $\times$ & $\checkmark$ & $x$ & $\checkmark$ & $\times$ & $x$ \\
\hline Acinetobactersp. & 1 & 1.4 & $\checkmark$ & $\times$ & $\times$ & $x$ & $\times$ & $\times$ & $x$ \\
\hline Enterobactersp. & 6 & 8.5 & $\checkmark$ & $\checkmark$ & $\checkmark$ & $\checkmark$ & $\checkmark$ & $\checkmark$ & $x$ \\
\hline Staphylococcusepidermidis & 3 & 4.2 & $x$ & $\times$ & $\checkmark$ & $\checkmark$ & $\checkmark$ & $\times$ & $x$ \\
\hline Bacillussp. & 1 & 1.4 & $x$ & $\times$ & $\times$ & $\checkmark$ & $x$ & $\times$ & $x$ \\
\hline Staphylococcussp. & 1 & 1.4 & $x$ & $x$ & $x$ & $\checkmark$ & $x$ & $\times$ & $x$ \\
\hline Pseudomonassp. & 3 & 4.2 & $x$ & $\times$ & $\checkmark$ & $x$ & $\checkmark$ & $\checkmark$ & $x$ \\
\hline Streptococcusmutans & 2 & 2.8 & $x$ & $\times$ & $\checkmark$ & $x$ & $\checkmark$ & $\times$ & $x$ \\
\hline TotalBacteria & \multicolumn{9}{|l|}{46} \\
\hline Overalltotal & 46 & \multicolumn{8}{|c|}{64.8} \\
\hline Diversity & 46 & & 8 & 7 & 9 & 11 & 4 & 5 & 3 \\
\hline \%diversity & 46 & 100.2 & 17.4 & 15.2 & 19.6 & 23.9 & 8.7 & 10.9 & 6.5 \\
\hline
\end{tabular}

Table 2: Frequency of occurrence of bacterial isolates in fried chicken tissues sold in Benin Metropolis.

similar to those reported by Saad which recorded that the mean values of aerobicplate count examined samples of fast foods were $3.92 \times 10^{4} \pm$ $0.57 \times 10^{4} \mathrm{cfu} / \mathrm{g}$ for grilled beefkofta; $6.33 \times 10^{4} \pm 1.84 \times 10^{4} \mathrm{cfu} / \mathrm{g}$ for fried beef burger; $4.78 \times 10^{5} \pm 0.96 \times 10^{5} \mathrm{cfu} / \mathrm{g}$ for friedchicken meat; $7.26 \times$ $10^{5} \pm 2.0110^{5} \mathrm{cfu} / \mathrm{g}$ for fried chicken kofta and $1.89 \times 10^{6} \pm 0.27 \times 10^{6}$ $\mathrm{cfu} / \mathrm{g}$ for fried chicken Pattie. FAO [21,22], stated that bacteria counts that is greater than or equalto $10^{6}$ cells per gram and Enterobacteriaceae counts greater than or equal to $10^{5}$ cells per gram are dangerous and could result to some health problems like food poisoning and intoxication. From the results obtained, the values of bacterial counts were above stated dose i.e. infective dose that will cause or pose a health risk. Laboratory prepared fried chicken served as control, had mean fungi count of $4.70 \times 10^{5} \mathrm{cfu} / \mathrm{g}$; the street vended chicken range from $1.385 \times 10^{6}$ to $2.615 \times 10^{6} \mathrm{cfu} / \mathrm{g}$ and the friedchicken from the eatery ranged between $7.85 \times 10^{5}$ to $1.9 \times 10^{6} \mathrm{cfu} / \mathrm{g}$. Statistical analysis of the mean fungi load showed no significant difference $(\mathrm{P}>0.05)$ between the street vended chicken and eatery in IkpobaOkha, Oredo and Egor Local Government Areas. The results obtained in this study are nearly similar to the findings of Woguet al. [23]. Their findings indicated that the microbial load of RTE rice from both local fast food centers (Local restaurants) and standard fast food centers (High class restaurants) in Benin City, had Total colony count range from $2.0 \times 10^{4}$ to $1.2 \times 10^{6}$ for 
Citation: Osakue OP, Igene JO, Ebabhamiegbebho PA, Evivie SE (2016) Proximate Analysis and Microbial Quality of Ready-To-Eat (RTE) Fried Chicken Parts. J Food Ind Microbiol 2: 107. doi:10.4172/2572-4134.1000107

Page 6 of 8

\begin{tabular}{|c|c|c|c|c|c|c|c|c|c|}
\hline \multirow[t]{2}{*}{ Isolates } & \multirow[t]{2}{*}{ No } & \multirow[t]{2}{*}{ Percent } & \multicolumn{2}{|c|}{ IkpobaOkha } & \multicolumn{2}{|c|}{ Oredo } & \multicolumn{2}{|c|}{ Egor } & \multirow[t]{2}{*}{ Control } \\
\hline & & & Street & Eatery & Street & Eatery & Street & Eatery & \\
\hline Aspergillusniger & 7 & 9.9 & $\checkmark$ & $\checkmark$ & $\checkmark$ & $\checkmark$ & $\checkmark$ & $\checkmark$ & $\checkmark$ \\
\hline Mucormucedo & 5 & 7 & $\checkmark$ & $\checkmark$ & $\times$ & $\checkmark$ & $x$ & $\checkmark$ & $\checkmark$ \\
\hline Cladosporium sp. & 2 & 2.8 & $\checkmark$ & $\times$ & $\checkmark$ & $\times$ & $\times$ & $\times$ & $x$ \\
\hline Penicilliumoxalicum & 4 & 5.6 & $\checkmark$ & $\times$ & $\checkmark$ & $\checkmark$ & $\checkmark$ & $x$ & $x$ \\
\hline Yeast & 4 & 5.6 & $\times$ & $x$ & $\times$ & $\checkmark$ & $\checkmark$ & $\checkmark$ & $\checkmark$ \\
\hline Aspergillusnidulans & 1 & 1.4 & $\times$ & $\times$ & $\checkmark$ & $\times$ & $\checkmark$ & $X$ & $\times$ \\
\hline Penicilliumitalicum & 2 & 2.8 & $\times$ & $\checkmark$ & $\times$ & $x$ & $\checkmark$ & $x$ & $\checkmark$ \\
\hline Total fungi & 25 & & & & & & & & \\
\hline Overall total & 25 & 35.1 & & & & & & & \\
\hline Diversity & 25 & & 4 & 3 & 4 & 4 & 3 & 3 & 4 \\
\hline$\%$ diversity & 25 & 100 & 16 & 12 & 16 & 16 & 12 & 12 & 16 \\
\hline \multicolumn{10}{|c|}{$\checkmark$ Means Present; $X$ Means Absent } \\
\hline
\end{tabular}

Table 3: Frequency of occurrence of fungi isolates in fried chicken tissues sold in Benin Metropolis.

\begin{tabular}{|c|c|c|c|c|c|c|c|c|c|}
\hline & \multirow[t]{2}{*}{ No } & \multirow[t]{2}{*}{ Percentage } & \multicolumn{2}{|c|}{ IkpobaOkha } & \multicolumn{2}{|c|}{ Oredo } & \multicolumn{2}{|c|}{ Egor } & \multirow[t]{2}{*}{ Control } \\
\hline & & & Street & Eatery & Street & Eatery & Street & Eatery & \\
\hline Total microbial & 71 & & & & & & & & \\
\hline Overall total & 71 & 99.9 & & & & & & & \\
\hline Diversity & 71 & & 12 & 7 & 15 & 11 & 12 & 8 & 7 \\
\hline Diversity Percent & 71 & 101.2 & 16.9 & 9.8 & 21.1 & 15.5 & 16.9 & 11.2 & 9.8 \\
\hline
\end{tabular}

Table 4: Sum total of microbial isolates in fried chicken tissues sold in Benin Metropolis.

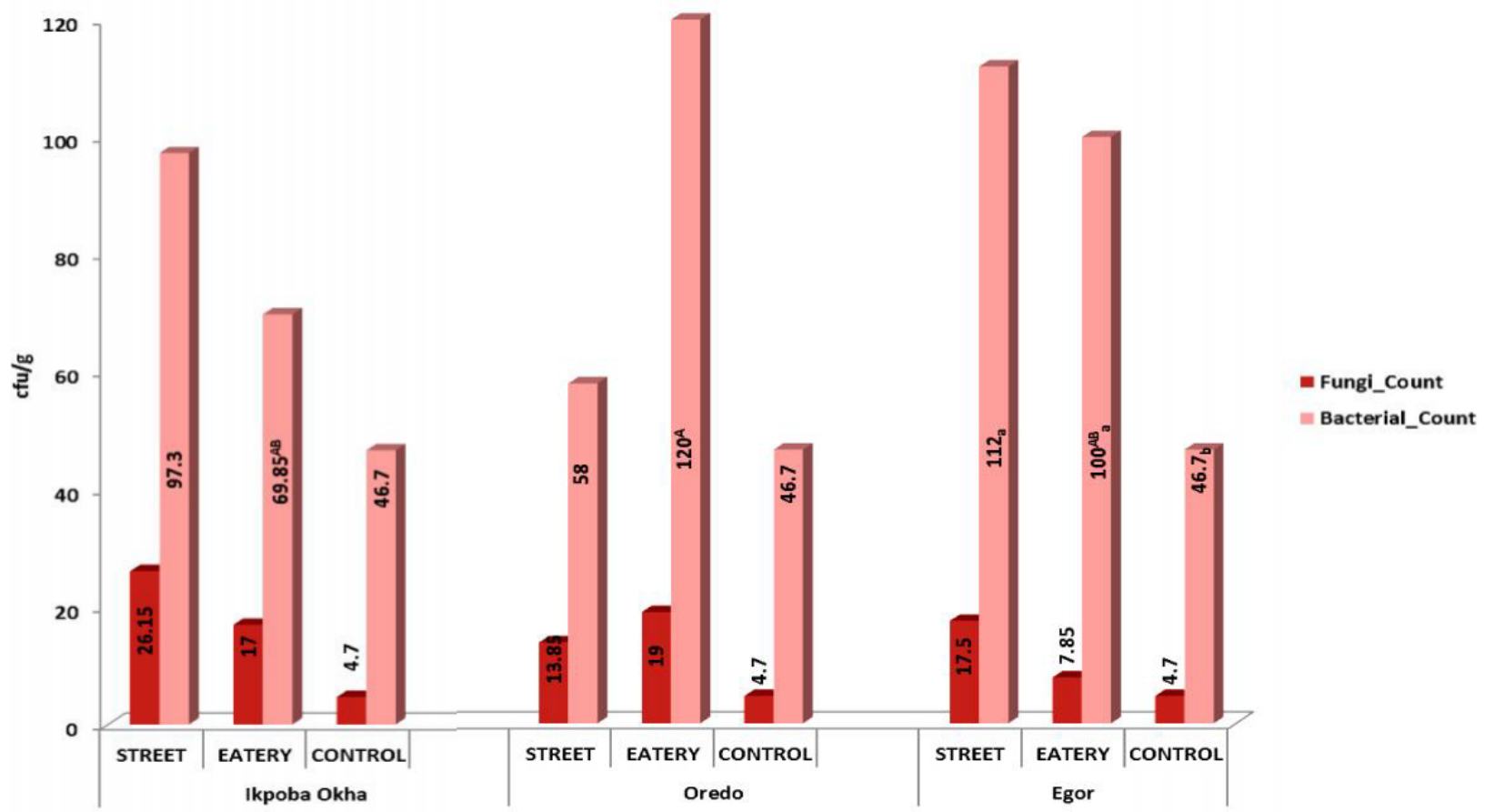

Figure 2: Microbial counts of fried chicken tissues sold in Benin Metropolis. Mean value with subscript shows significant difference $(P<0.05)$ within each LGA. While mean values with superscript shows significant difference $(P<0.05)$ across $L G A s$. 
bacteria and $8.0 \times 10^{4}$ to $2.0 \times 10^{5}$ for fungi. Their result also showed that the standard fast food centers had more microbial load and more microorganisms compared to RTE rice from local fast food centers.

The frequency of occurrence (\%) of each microbial isolate was also determined (Tables 2 and 3). The highest number of isolates was obtained from fried chicken sold in the eatery in Oredo with a percentage diversity of $21.1 \%$ (Table 4 ). This was followed by the street fried chicken sold in Ikpobaokha and Oredo (16.9\%), eatery in Ikpoba Okha (15.5\%), eatery in Egor (11.2\%) and street vended chicken in Egor and the control (9.8\%). The frequency of occurrence of bacteria isolates was higher than the fungi isolates. Forexample,Proteus $s p$ andStaphylococcus aureus (9.9\%) were the most frequently isolated organisms from all the friedchicken samples. Aspergillus niger had a frequency of $(9.9 \%)$. It was the only fungi isolated from all the fried chicken samples. This was followed by Micrococcus $s p$. and Enterobacter sp.(8.5\%), Streptococcus sp, Escherichia coli, Klebsiella sp, Staphylococcus epidermidis, and pseudomonas $\mathrm{sp}(4.2 \%)$, Streptococcus mutans (2.8\%) andAcinetobacter sp, Bacillus sp. andStaphylococcus $s p(1.4 \%)$. While Aspergillus niger (9.9\%) was the most frequently isolatedfungi followed by Mucormucedo (7\%), Penicillium oxalicum and Yeast (5.6\%), Cladosporiumspand Penicillium italicum (2.8\%) and Aspergillus nidulans (1.4\%) which where the leastfrequent fungi isolates implicated in this study.

In this study, thirteen genera of bacteria were isolated from fried chicken. The isolates were identified as Proteus $s p$, Micrococcus $s p$, Staphylococcus aureus, Streptococcus s.,Escherichia coli, Klebsiella $s p$, Acinetobacter sp, Enterobacter sp, Staphylococcus epidermidis, Bacillus sp, Staphylococcus sp, Pseudomonas sp and Streptococcus mutans. Thefungi isolated include Aspergillus niger, Mucormucedo, Cladosporium sp, Penicilliumoxalicum, yeast, Aspergillus nidulansand Penicillium italicum. This is in agreement with Clarence et al. [24] that isolated six genera of bacteria which include Staphylococcus sp, E.coli, Klebsiella sp, Pseudomonas sp, Bacillus spand Enterococcus sp. This result is also inagreement with the work of Oluwafemi and Simisaye [25] and Okonko et al. [26] where they isolated almost similar organisms from sausages and seafood respectively. Oranusi and Braide [5], isolated Aspergillus niger from ready-to-eat foods sold along Onitsha- Owerri highway. He stated that mishandling of food products could lead to proliferation of fungi beyond acceptable limits. The presence of these organisms in ready-to-eat food (Fried chicken) depicts a deplorable state of poor hygiene and sanitary practices employed in the processing and sales ofthese food products. Also, the presence of fungi such as Aspergillus niger in the food signals danger to public health since many of these fungi are toxin-producing organisms.

It is apparent from this investigation that the presence of coliforms in the street meat as compared to the eateries and the control could be a reflection of the level of exposure, and the handling processes in these two vending sites. In the open market the products are left exposed without any form of packaging or covering as often as the customers' demand. This open displayof products is to attract the customers and this encourages sporadic visits by flies. The dusty, unhygienic market environments coupled with the poor handling by the vendors are factors contributing to the high microbial load. The common practice of using same utensils for picking meat (cross contamination) could also be responsible for the microbial loads obtained even from fried chicken gotten from the eateries [27]. Vendors of ready-to-eat fried chicken usually make use of simple facilities like wheel barrows, trays, tables and make-shift stalls, thus further increasing the risk of food contamination. Pathogens may invade the exterior parts of the meat during processes like handling and packaging [28]. The chances of contamination both in the street vended fried chicken and the eateries may be further heightened by the fact that, fried chicken is sold without adequate storage conditions. This practice exposes the fried meat to flies as for the street meat and maintains the product at optimum temperatures for microbial invasion and proliferation of contaminants such as pathogenic mesophiles and other diseasecausing agents as for the eateries. The fried chicken are processed and sold by poorly educated and untrained vendors in food hygiene $[9,28]$. Poorly processed street vended product (insufficient frying) has been identified as an important cause of diseases in developing countries [29,30]. Bacillus sp, Penicillium spand Aspergillus spwere present in most of the samples. This could be due to thefact that these organisms are spore formers and are known common environmental contaminants. However these organisms have been implicated as food borne pathogens [31-33]. The growth of Bacillus spp in fried chicken was ascribed to its presence in the raw materials in spore form which survived cooking; possibly coupled to its reintroduction into the fried meat through post-cooking contamination. Staphylococcus aureus is a normal body flora of humans found on nasal passages, skin and mucous membranes and could have been introduced through unclean hands and mouth of the preparer, vendor and/or customers [34,35]. The packaging materials (usually cellophane) are normally opened by squeezing/blowing air into it. The presence of Staphylococcus aureus could also be attributed to the raw ingredients used (raw tomato sauce, raw sliced onion), unclean utensils and poor environment in which the food is prepared. Staphylococcus aureus is an opportunistic pathogen; and the Enterotoxigenic strains of it are known to cause serious foodborne disease [32,36]. The presence ofEscherichia coli, Klebsiella sp, proteus $s p$ and Enterobacter sp calls for concern as these organisms are frequently associated with poor sanitarypractices and could be a pointer to the danger of possible food-borne infection. Escherichia coli are especially of fecal origin and have been implicated in numerous food-borne diseases [11,33]. The vendors, water, environmental pollution and inadequate washing of hands and utensils appear to be the major causes of the hazard associated with this fried chicken and must be addressed properly. It is interesting to note that high temperature through boiling and frying is commonly involved in the preparation of fried chicken, which is sufficient to eliminate most of the microorganisms. However, post-processing contamination may occur when the product is not appropriately handled and packaged; this affects the quality of the final product. Since Escherichia coli which is one of the most important food-bornepathogen,wasisolatedf romthestreetvendedfriedchickensamples, the consumption of this food should be discouraged especially since the food is left exposed without any form of heating. Otherwise, the food should be reheated before consumption. However, in spite of the hygienic processing done to the laboratory prepared fried chicken (control) the microbial counts were high. This clearly and /or probably was due to the challenges encountered in the laboratory. The contamination might have come from the working environment.

\section{Conclusion}

The result of this study indicated that the fried chicken sample obtained from all thesampled areas in this study were microbiologically (bacteria) unsafe for consumption. Properprocessing of the food under hygienic conditions so as to reduce the risk of contamination isrequired

\section{References}

1. Adamolekun WE, Adamolekun B (1992) Bacteria associated with food processing. NigMed 24: 43-45. 
Citation: Osakue OP, Igene JO, Ebabhamiegbebho PA, Evivie SE (2016) Proximate Analysis and Microbial Quality of Ready-To-Eat (RTE) Fried Chicken Parts. J Food Ind Microbiol 2: 107. doi:10.4172/2572-4134.1000107

Page 8 of 8

2. Angelides AS, Chronis EN, Papageorgio DK,Kazakis $\mathrm{H}$, Arsenoglou KC, et al. (2006) Non lactic and contaminating flora in ready-to-eat foods: A potential food quality index. Food Microbiology 23: 95-100.

3. Bas M, Ersun AS, Kivanc G (2006) The evaluation of food hygiene knowledge, attitudes and practice of food handlers in food business in Turkey. Journal of Food Control 17: 317-322.

4. Beuchat LR, Ryu JH (2007) Procedure handling and process practices. Emerging Infectious Diseases 3: 459-465.

5. Blumenthal MM, Stier RF (1991) Optimization of deep-fat frying operations. Trends Food Sci Tech 2:144-148.

6. Bryan FL, Tuefel P, Rooh S, Qadar F, Riaz S, et al. (1992) Hazards and Critical control points of food preparation and storage in homes in a village and a town in Pakistan. J Food Protection 3: 301-333.

7. Cencil GBT, Karma M, Rositto PV, Morgante RA, Cullor JS, et al. (2003) Enterotoxin production by Staphylococcus aureus isolated from mastitic cows. J Food Prot 66: 1693-1696.

8. Dolores GE, Doyle JG (2001) Escherichia coli in diarrhea disease. Ann Int Med 247: 81-90.

9. Draper A (1996) Street foods in developing countries: The potential for micronutrient fortification. John Snow, INC/OMN. Project London School of Hygiene and Tropical Medicine.

10. Duff SB, Scott EA, Mastilios MS, Todd EC, Krilov LRG, et al. (2003) Cost effectiveness of a target disinfection program in household kitchens to prevent food-borne illnesses in the United States, Canada and the United Kingdom. J Food Protect pp: 2103- 2105

11. Tinker I (1985) Equity Policy Centre utilizing the Street Food trade in Development Programming: Final report, Washington DC: Equity Policy Center.

12. Frazier WC, Westhoff DC (2008) Food Microbiology ( $3^{\text {rd }}$ edn.). McGraw Hill Company Incorporation, New York p: 540.

13. Frazier WC, Westhoff DC (2009)Food Microbiology(6 $6^{\text {th }}$ edn.). McGraw Hill Company Incorporation, New York p: 742.

14. Freese E, Romero-Abal ME and Solomon NW (1998) The street food culture of Guatemala City: A case study from a down-town, urban park. Arch. Latinoam Nutr 48: 95-103.

15. Geraldine D, Brendan K, Fitz-maurice J, Sheridan JJ (2001) Routine diagnostic tests for food-borne pathogens. The National food centreTeagase, Dunsinea, Castleknock, Dublin 15: 1-4.

16. Giese J (1996) Fats,oils and fat replacers. Food Tech 50: 78-84

17. Gilbert RJ, Louvois J, Donovan T, Little C, Nye K, et al.(2000) Guidelines for the microbiological quality of some ready-to-eat food samples at the point of sale. PHLS Advisory Committee for Food and Dairy Products Commun. Dis Public Health 3: 163-167.

18. Gill C, Newton K (1997) The development of Aerobic spoilage flora on meat stored at chill temperatures. Journal of Applied Bacteriology 43: 189-195.
19. Zariwala A, Sanders Q, Hudson CR, Hofacre C, Thayer SG, et al. (2002) Distribution of Staphylococci enterotoxin genes among Staphylococcus aureus isolates from poultry and humans with invasive Staphylococcal disease and Avian Diseases 46: 132-136.

20. Igene JO, Abulu EO (1984) Nutritional and bacteriological characteristics of Tsire-Type Suyaa popular Nigerian meat product. J Food Prod 47:193-196.

21. Igene JO (1983) Total plate count and Coliform density for retail suya. Trop Veterinarian 1: 85-91.

22. International Commission on Microbiological Specifications for Foods (1986) Microorganisms in foods sampling for microbiological analysis, $\left(2^{\text {nd }} e d n.\right)$, Univ Toronto Press, Toronto.

23. Jindal V, Bawa AS (1988) Utilization of spent hens and soy flour in the preparation of poultry sausages. $\mathrm{J}$ of meat science 1: 23-27.

24. Kumar P, Clark M (2002) Kumar and Clark Clinical Medicine $\left(5^{\text {th }}\right.$ edn. $)$, Edinburgh: W.B. Saunders, pp: 75-76.

25. Muleta D, Ashenafi M (2001) Salmonella, Shigella and growth potential of other food-borne pathogens in Ethiopian street vended foods. East Africa Med J78: 576-580.

26. Nguz K (2007) Assessing food safety system in sub-saharan countries: An overview of key issues. Food Control 18: 131-134.

27. Olomu JM (2011) Monogastric Animal Nutrition: Principles and Practicepp: 25 427.

28. Oteri T, Ekanem EE (1989) Food hygiene behavior amongst hospital food handlers. Public Health 103: 153-159.

29. Park K (2004) Park's textbook of Preventive and Social Medicine $\left(25^{\text {th }}\right.$ edn.) Jabalpur: Banar sides Bhanot pp: 104-181.

30. Pokorny J (1999) Changes in nutrients at frying temperatures. In: Boskou D (edn.) Frying of foods. Romanian Biotechnological letters.

31. Powel D, Bradber E, Campbell V (1990) Street foods of Kingston, Jamaica Institute of Social and Economic Research, University of the West Indies.

32. Prescott M, Harley P, Klan DA (2005) Microbiology (6thedn.), McGraw Hill New Yorkpublishers USA.

33. Rajashekara G, Drozd M, Gangaiah D, Jeon B, Liu Z, et al. (2009) Functional Characterization of the twin-arginine translocational system in Campylobacter jejuni.Food-borne Pathogen Dis 6: 935-945.

34. Ryser ET, Arimi SM, Bunduki MM, Donnelly CW (2006) Recovery of different Listeria ribotypesfrom naturally contaminated, raw refrigerated meat and poultryproducts with two primary enrichment media. Applied Environment Microbiology 62: 1781-1787.

35. Mohmoud SS, Ibrahim HM, Alla EA, Mohamed A (2011) Microbial and chemical evaluation. Journal Of Food Chemistry.

36. Sotelo A, Perez L (2003) Nutritive value of chicken and potato mixtures for infant and preschool children feeding. J Sci FoodAgric 83: 1205-1209. 